immediate and the patient slept well the first night and next day was much improved in appearance, and said she felt almost well-the head and stomach symptoms were all gone. The ear was discharging freely, and we injected a solution of peroxid of hydrogen and watched the bubbles escape through the perforated drum membrame, and the entire external canal became filled with the same, and the patient coughed the froth out of her throat and blew it out of her nose. Afterward a one-half per cent. warm solution of carbolic acid was injected and last of all an alcoholic solution of boric acid was used and the latter caused considerable temporary pain. The mastoid wound was dressed in the usual way and the nose and throat treatment was continued. So rapid and marked an improvement resulted from the daily treatments that at the end of four days the ear discharge had almost ceased and what little was still present was thin, pale and watery, and seen only in the neighborhood of the perforation in the drum membrane. At the end of one week from the initial injection of the mastoid a mere speck of watery moisture at the site of the drum perforation was mopped up on cotton, and on examination, per microscope, was seen to consist of detritus, with a few granular, breaking down, and fissured pus cells. Ear treatment was now discontinued. A plug of cotton was kept in the external auditory canal, and the mastoidal wound was allowed to close. In another week the tympanic perforation and the wound of the mastoid had healed and the case was dismissed with the request that the nasal douchings be continued. The cure was complete, and it proved to be permanent as no relapse has since occurred. One year later the hearing distance for the watch was 11-40, whereas for the left ear it was $40-40$, and the tuning fork was heard in all positions, better in the right ear. In all, the diseased process had lasted about fifty-eight days in the right ear, but a complete and thorough drainage and antisepsis of the infected cavities had been instituted for only four to seven days before a perfect and permanent cure resulted. This is the indication in all suppurative processes, but it is notably difficult to accomplish in aural surgery without opening up freely the suppurating cavities. This case shows, however, that, even as dangerous as conservative surgery is in such ominous cases, very occasionally a cure may result from simple methods.

16 Laflin Street, Chicago, Ill.

\section{THE CHURCH OF ROME AND THE LEPERS OF COLOMBIA}

BY ALBERT S. ASHMEAD, M.D.

NEW YORK.

I send you an appeal of the order of St. Lazarus for help to the unfortunate lepers of Colombia. Formerly the grand master of this order had to be a leper himself. His Grace, the Archbishop of New York, informs me that this manner of qualification for the grandmastership was abolished by the Holy See in 1253 .

\section{LECTURE.}

Lecture given by the Reverend Father (Salesian) Evasio Rabagliati, in the Solemn Session of the Society of St. Lazarus (Bogota, Colombia) on July 7, 1895. (Exordio-Et occurrerun ei decem viri leprosi, qui steterunt a longe et levaiverunt vocem suam dicentes: Jesu preceptor, miserere nostri-and there met him ten men that were lepers, which stood afar off; and they lifted up their voice and said: "Jesus, Master, have mercy on us." ")

The first thing we should observe in this story is the great and exquisite kindness of Jesus, etc.

Brethren, not far from here, not one, not ten, lepers lift their voices, there are many more. In Agua de Dios there are 850, in Contratacion (Santander) I left, a few months ago, 700 and more; and all these lift their yoices, in order that you may hear them. And what do they say? What is their plea? The same as that of the gospel, miscrere nostri, have pity on us.

Until to-day, according to data gathered in a private manner, I believed that the number of lepers of Colombia did not exceed 15,000 or 16,000 . Now, I see that I was mistaken. Before I ascended this pulpit one of our physicians, Dr. Carlos E. Putnam, member of the Academy of Medicine, Bogota, assured me that I was; for he, after asking from all the departments the precise number of the patients, obtained this result: That the number of lepers in the whole Republic of Colombia on July 6,1895, amounts to 27,250! Is there an error in this account? Who knows? For my part, I will admit an exaggeration; I will suppose that there is an error in the figures; I will try to believe that the number does not reach 20,000 , even less; that there are not more than 15,000. Do you think that if we can abate a few thousands of the official account, this is an argument that ought to quiet us? Even thus, do you not believe that the calamity is great, and that the consequences for the future would be serious and baneful.

During fifteen years which I passed in the Argentine Republic, in Uruguay and in Chili, I did not see one leper. If anyone should take the time and patience to gather precise data on this subject, "Leprosy in the World," the result would be, that the Republic of Colombia alone has more people attacked by leprosy in its different manifestations than all the other nations of the universe. Really such a thing is amazing and terrible. . . Let us ask the men of science, the physicians; they all, unanimously, will tell us that the principal causes of this disease are heredity and contagion. As to heredity, there is not the least doubt; the Lazarinos themselves acknowledge that either the children or the grandchildren inherit the disease; the germ remains. Who is able to say what enormous proportions the disease must assume through this cause? As to the contagiousness, not being competent I shall give no opinion. All the Lazarinos say that the disease is not contagious. Almost all the physicians say that it is; and $I$ have said almost all because in the medical congress held at Bogota about two years ago, of more than one hundred physicians called upon to give an opinion on the matter, only two said, No. All the others answered in the affirmative. Who was mis. taken? The two or the ninety-eight? But I give my opinion, whatever its value. I believe there are climates unfavorable to the disease, and that others favor it. In the first place there will be nocontagion, or it will be very slight; in the other case there will

1 And it came to pass, as he went to Jerusalem. that he passed through the midst of Samaria and Galilee. And as he entered iuto a certain village, there met him ten men that were lepers, which s ood afar off. And they lifted up their voices and said: "Jesus, Master, have mercy on us. And when he saw them, he said unto them: "Go show yourselves unto the priests." And it came to pass that as they went they were cleansed. And one of them when he saw that he was healed face back, and with a loud roice glorified God. And fell dow $n$ on his answerin feet, giving him thanks, and he was a Samaritan. And Jesus answering, said: "Were there not ten cleansed. but where are the nine. There are not found that returned to give glory to God save this stranger." And he said unto him: "Arise, go thy 
be contagion and it will manifest itself rapidly and energetically.

One fact most evident is that the evil increases every year. In the year 1888, according to the statistics of the Lazarinos of the Department of Santander, which were made conscientiously by one of the most distinguished physicians of that Department, the number of patients in that year did not reach 1,500; in October of the next year, I think, I met from 5,000 to 6,$000 ;$ I have since heard from persons of competent authority that $I$ had been very much mistaken, for in the department in question there are not less than 10,000 lepers. 'There is another fact which is evident. A few years ago this disease was totally unknown in Antioquia; now it is frequently seen there. In the Cauca we hear the same story; the number of the lepers can not be very small, when we consider that the authorities of that department have decided to establish a lazaretto for their exclusive use.

Allow me to speak with entire frankness. The public in general believe that isolation exists, because we have a large lazaretto a few leagues from the capital, in Agua de Dios, and another lazaretto in Santander. That is true; but these lazarettos have only the name of a hospital, and I may say without the least exaggeration there might be written over the entrance of both, "Fabrication of Lazarines." I can tell you, even now, that in both these leper houses the healthy are much more numerous than the diseased; two healthy ones to one sick; this is the proportion of the population of the lazarettos. But what are the healthy people doing there? Some, the smaller number, probably attend to the patients; it is the healthy daughter who accompanies and attends her mother, or vice versa; it is a brother, some relative who does not want to forsake a sick brother or relative; to that there is nothing to say, it is a laudable act of charity which these healthy persons are performing, and God will not leave this work of love without reward. But, on the other hand, there are other healthy persons, the greater number, probably, who are there for other reasons. Some for the purpose of doing business, others with the infamous object of exploiting the poor lepers. On this subject, $T$ have been told in the Lazaretto of Contratacion of incidents that were really scandalous. Moreover, in both lazarettos he enters who will, and remains as long as he likes; he may even establish his residence there if the whim takes him to do so, without anyone having the right to interfere. . . . The attendants are generally healthy persons, who have to live in intimate contact with the diseased, eat at the same table, perhaps from the same plate, sleep under the same roof, use the same garments.

And now, tell me frankly your opinion, are these lazarettos just as we see them, places of danger, or are they not? You must consider, that from these houses the lepers may go to other places and establish themselves in the villages with the greatest facility. Any pretext is good; if there is none, one is invented. It is not the President of the Republic who gives these permissions, not even the alcalde of Tocaima, which is the nearest place to the lazaretto. They may be given simply by the administrator or a person delegated for that purpose.

We recognize the necessity for a large and unique lazaretto; but where? The prospect of the island of Coiba, in the Pacific ocean, as a place of isolation has entirely failed for many reasons; and the most forcible of these, in my opinion, was the obstinate resistance of the lepers. They have told me over and over again, on all occasions, "We shall flee to the woods, Father, we shall hide in the mountain caves, we prefer starving here; but to the island we shall not go." I have consulted reliable persons on this matter, and they have pointed out to me the plains of Casanare, or of San Martin. The idea of taking Casanare could not be considered, because it is a region very little adapted; 1 , because these plains have a large population; 2, because the inundations are frequent during many months of the year. In San Martin it is very different; the rivers are not so numerous nor so rapid; we can find with exceptionably favorable conditions, a great plain, surrounded by the Meta and Nare Rivers, which form a very beautiful peninsula several leagues in extent, the elevation rendering flooding impossible, however rainy the winter may be; and it has other advantages not necessary to enumerate here. As to population we may say it has none; it is a desert pure and simple.

The successor of Don Bosco, the present superior of the Salesian order, Don Miguel Rua, long ago solemnly promised the representative of Colombia in Rome, the most excellent Dr. D. Joaquin Vélez, to send as many monks to Colombia as was necessary to execute this project. In one of his last letters, dated from Bogota, he approved and blessed it and encouraged us to begin to execute that great idea. The friend and father of the Lazarines, Father Miguel Unia, also approved the project, and thinks it feasible; he, who is speaking to you, has received from his superiors of Turin all the means necessary to consecrate himslf exclusively to this mission, and after the feasts of Our Lady of Carmen he will be entirely at the disposition of the public. He will fulfill his promise and begin his journey from place to place through the whole extent of the republic to ask for the mite of Colombian charity; if this shall be the decision of this conference. I wish before starting, to speak to you again; in order to further elucidate these ideas, and answer the objections which may be made. In the meanwhile, to the intelligent, distinguished and charitable people of the capital, I intrust the project. To all, without distinction of opinion, either religious or political, I recommend it most seriously; study it, discuss it, amend it also, if you see fit. What is important to all is to arrive at satisfactory and feasible solution. Especially do I intrust it to you, men of science and of arts, to the physicians and publicists; adopt this project, make it your own, and let your valuable opinion be spread to the last confines of the republic, in order to fill with hope the heart of all lepers, and with charity and generosity the hearts of all Colombians.

My last word is for you, virtuous and devoted Sisters of the Society of San Lazaro. May God bless you for all the good you have done during the four years of existence of your beloved society. Forward, with perseverance, you have done much; but there remains immeasurably more to do; enlarge the sphere of your activity, increase your ranks; every Colombian whose heart beats with love of religion and fatherland must enter them. Your work is a work of redemption above all others. Do not be discouraged by the difficulties which you will meet; remember that every great and holy work must bear the seal divine, the seal of contradiction and struggle. Once passed through the crucible, the work will prosper 
and triumph. God certainly has blessed and is blessing us now, for his Vicar on earth, the Sovereign Pontiff Leo XIII, has blessed you and blesses you now. You find the proof of that in the treasure of indulgences, partial and plenary, which he sent you last year. Be ye all enthusiastic propagandists for the project which I have announced; and with your fervent and constant prayers help the work which we undertake.

In the name of God, in the name of your wards, the lepers of Agua de Dios, in the name of religion and fatherland, I send you the most sincere thanks. And for all you have done, and all you may do in the future, all the glory will be solely for God and the salvation of souls.

Ad Majorem Dei Gloriam. I have said. PASTORAL.

We, Bernardo Herrera Restrepo, by the grace of God and of the Holy Apostolic See, Archbishop of Bogota, to the clergy and to the faithful of the Archdiocese:

All the good sons of Colombia who are animated with Christian charity toward their fellow men, are deeply concerned by the sad situation in which are placed so many of our brethren, who suffer this terrible disease of leprosy and its painful and inevitable consequences of isolation and perhaps of abandonment and utter want.

The church could not do less than take part in that general solicitude; and, therefore, if in other times and in similar circumstances, men especially called to help the poor diseased arose from among her ministers, now, too, by means of the sons of Don Bosco," she gives examples of love for the unfortunate lepers. They with the spirit of sacrifice which is above all praise, live among these unfortunates, nursing them as a father would, and offering them in life and death the consolations of religion.

Now the great work of the founding of the national lazaretto having been begun with the object of insuring to the lepers habitation and means of subsistence to make their lives less bitter and of opposing the spread of the contagion, the Salesian Fathers will announce and propagate this grand work in the whole republic. With that object, the Reverend Father Evasio Rabagliati prepares to journey about in the republic in order to persuade all to coöperate accord. ing to their means and to contribute with their alms and voluntary donations.

It is our duty to support this holy and charitable enterprise; and for that purpose, we appeal to the clergy and to the people of the republic, and especially of the city of the archdiocese entrusted to us, and we request everyone to give a hearing to the Christian sentiments of his heart, and to contribute as largely as he can to the founding of the national lazaretto, delivering into the hands of the Rev. Father D. Evasio Rabagliati the alms which he destines for that purpose.

Our Lord, God, will reward all those who help in this work of Christian love which we recommend; they will return an hundred-fold to the giver the goods which will be offered for the relief of those who cry like Job:" "Have pity upon me, have pity upon me, $O$ ye, my friends; for the hand of God hath touched me."

\footnotetext{
2 Brothers of the White Frock.

3 Job xix, 21 .
}

This pastoral shall be read twice in all the churches in the archdiocese. Given in Bogota, Aug. 4, 1895. BERNARDO,

Salustiano Gómez Riaño, Archbishop of Bogota. Canonical Secretary.

\section{CONGENITAL ABSENCE OF THE ESOPHAGUS.}

BY DANIEL LICHTY, M.D.

MEMBER OF THE AMERICAN MEDICAL ASSOCIATION ROCKFORD, ILL.

A writer in a late issue of the Journal, in an article on a subject remote from this, made the statement that "malformations of the internal organs of the fetus are still more rare than the various orthopedic lesions of the exterior body." In confirmation of this, a case of the above title came to my notice, whose rarity then impressed me, and it is here given to add to the peculiarities and mysteries of tissue growth in pre-natal life. If those who have the Index Medicus can find similar cases recorded in it, it would be interesting to know of them.

There was born in Rockford Hospital July 24, 1895, after a quite natural and easy labor, of a healthy Swedish mother aged 25, her third child, a male weighing six and three-fourths pounds, well formed and fully developed in all its external parts. After birth there was some of the obstructive mucous respiration often observed, which usually passes away after wiping the mouth, a drink of water, inverting the child and such like procedure. In this case, however, it persisted from day to day; it could nurse and seemingly swallow. There was nasal regurgitation, though the hard and soft palate and pharynx were perfectly normal; the gurgling respiration continued in spite of all efforts to relieve it, and on the eighth day the child died of inanition.

The privilege of a postmortem examination was obtained from the grieved but sensible parents. Exploration began by removing the sternum, dissecting through the thyroid isthmus, exposing and inspecting the larynx and trachea, which were each found normal except being filled with the ingested milk; a soft catheter was passed into the pharynx and esophagus which met obstruction that resisted further advance. Deeper dissection brought to light the esophagus ending in a distinct cul-de-sac, in which the tip of the catheter was engaged at the second dorsal vertebra. The lumen of the gullet was normal to this abrupt terminal. being about one centimeter in diameter, easily admitting a No. 12 catheter. Two centimeters below this and a little to the left, as would follow the normal course of the esophagus, began a fibrous impermeable cord one millimeter in diameter, very gradually increasing in size, in its passage through the diaphragm, until the natural dilatation of the stomach was attained, where its permeability was reëstablished, and the remainder of the alimentary tract was of normal form and function throughout. No other malformation was discovered.

Minnesota Coroner's Fees.-.-Where the coroner on the same day makes two separate examinations of two different dead bodies, or holds an inquest on one body and makes an examination of the other, the supreme court of Minnesota holds, in Kistler vs. Board of Commissioners of Hennepin County, decided June 24, 1896, that, under section 5554, General Statutes 1894, he is not entitled to a fee of five dollars for each examination and each inquest, or to anything more than five doliars per day " for the time actually spent." 